The Impact of COVID-19 pandemic on the Oil Sector in global economic ...

Dr/ Mona Aboul Atta Halim \& Dr/ Walaa Magdy Rezk

\title{
The Impact of COVID-19 pandemic on the Oil Sector in global economic and Saudi Economy
}

\section{Dr. Mona Aboul Atta Halim}

Assistant Professor of Economics, Financial Sciences

Department, The Applied College, Imam Abdulrahman Bin

Faisal University, P.O.BOX 1982Dammam 31441, Saudi Arabia.

e-mail: mahalim@iau.edu.sa

ORCID-ID : 0000-0001-9075-2801

\section{Dr. Walaa Magdy Rezk}

Assistant Professor of Economics, Financial Sciences

Department, The Applied College, Imam Abdulrahman Bin Faisal

University, P.O.BOX 1982 Dammam 31441, Saudi Arabia.

e-mail:wmrezk@iau.edu.sa

ORCID-ID : 0000-0002-6968-977X

\section{Abstract}

This study aimed to identify the impact of COVID-19 on oil sector which faced the significant challenges, globally and in Saudi Arabia. The study sheds light on the unprecedented crisis that occurred in the decline in demand for oil and the collapse of its prices, and its effects and consequences on world economies and Arab economies, and the extent to which the Saudi economy has been affected by them in light of what markets have witnessed global oil, and opportunities to benefit from this crisis and the study relied on the descriptive and analytical methodology. The study paper will use the NARDL to explain the asymmetric effect of changes in oil price on Government

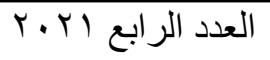

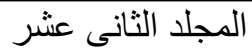


The Impact of COVID-19 pandemic on the Oil Sector in global economic ...

Dr/ Mona Aboul Atta Halim \& Dr/ Walaa Magdy Rezk

Budget for Saudi Arabia. The study reached that this situation provides a further opportunity for Saudi Arabia to diversify the economy away from a reliance on oil , Government policies seek to facing these challenges by diversifying the economic base and developing and diversifying revenues Non-oil products to reduce financial volatility, in addition to enhancing the role of the private sector focusing on supporting non-oil GDP growth rates to enhance the resilience of the economy.

Keywords: Oil Prices, Oil \& Gas sector crude oil futures, Saudi Arabia

\section{1-Introduction}

The oil markets witnessed in April 2020 a historic event, where the prices of American light crude collapsed below zero, in an unprecedented event, and the world will remember them for a long time, which raises questions about how this happens and its meaning, those affected by it and the potential or expected effects after That and such prices. The Corona pandemic was not the main reason for the decline in oil demand and the collapse of its prices in the manner that occurred, but the last actions by oil producers was the reason for increasing pressure in a market that was previously suffering.

This decrease in oil prices (American crude) came in the context of the global downturn in the COVID -19 pandemic that struck the world's economies in a recession, causing the demand for points to drop by nearly a third, in addition to the disturbances

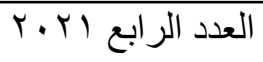

المجلد الثاني عشر 
The Impact of COVID-19 pandemic on the Oil Sector in global economic ...

Dr/ Mona Aboul Atta Halim \& Dr/ Walaa Magdy Rezk

that dominated the relations of OPEC members, After Russia withdrew from the Alliance of Oil Producers, which was aiming to balance the market, in early March 2020.

And where there are producing countries that produce oil, there are other countries that store only, and based on the agreement of the OPEC countries, the producing countries must maintain the equivalent of 90 days of oil reserves, to face any crisis, especially in times of war. However, it did not happen that the OPEC member countries kept this amount of reserves, until the COVID -19 pandemic came and caused the demand for oil to drop, and the rates of over storage increased dramatically - due to the oversupply increase to 35 million barrels per day. - Exceeds the actual storage capacity in countries that do so.

In this context, this research paper attempts to shed light on this unprecedented crisis and its effects and consequences on the global economy, the extent to which the Saudi economy was affected by it and the opportunities to benefit from this crisis.

\section{2-Literature Review}

The oil and gas industry is experiencing its third price collapse in 12 years. After the first two shocks, the industry rebounded, and business as usual continued. This time is different. The current context combines a supply shock with an unprecedented demand drop and a global humanitarian crisis. Additionally, the sector's financial and structural health is worse than in previous crises. The advent of shale, excessive supply, and generous financial

$$
\text { العدد الر ابع I.r. }
$$$$
\text { المجلد الثاني عشر }
$$ 
The Impact of COVID-19 pandemic on the Oil Sector in global economic ...

Dr/ Mona Aboul Atta Halim \& Dr/ Walaa Magdy Rezk

markets that overlooked the limited capital discipline have all contributed to poor returns. Today, with prices touching 30-year lows, and accelerating societal pressure, executives sense that change is inevitable. The COVID-19 crisis accelerates what was already shaping up to be one of the industry's most transformative moments.

The pandemic is first and foremost a humanitarian challenge, as well as an unprecedented economic one. The industry has responded with a Herculean effort to successfully and safely operate essential assets in this challenging time. The current crisis will have a profound impact on the industry, both short and long term. How radically the oil and gas ecosystem will reconfigure, and when, will depend on potential supply-demand outcomes and the actions of other stakeholders, such as governments, regulators, and investors. In any scenario, however, we argue that the unprecedented crisis will be a catalytic moment and accelerate permanent shifts in the industry's ecosystem, with new future opportunities.

Taking bold action during the crisis to secure resilience and accelerated repositioning Hard questions, indeed. In the meantime, winners will accept the crisis for what it is: a chance to form their own views of the future and to lead to capture new opportunities. Leaders will adopt tailored strategies that fit within their specific environment and markets in which they choose to compete, and the capabilities they bring (such as low-cost

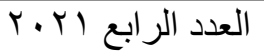

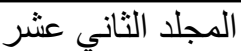


The Impact of COVID-19 pandemic on the Oil Sector in global economic ...

Dr/ Mona Aboul Atta Halim \& Dr/ Walaa Magdy Rezk

production, regional-gas or downstream-oil market leadership, value-chain integration, and specialized strengths in for example retail, trading, and distribution). In our view, all companies should act boldly on five themes, consistent with their chosen strategy: Reshape the portfolio, and radically reallocate capital to the highest-return opportunities, Take bold M\&A moves, Unlock a step-change in performance and cost competitiveness through re-imagining the operating model, Ensure supply-chain resilience through redefining strategic partnership approaches, Create the Organization of the Future, in both talent and structure (Mckinsey,2018).

ALOUI (2020) indicated that on 12 March 2020, the sharp fell of U.S. crude oil price to 30 dollars was explained by the outspreads of coronavirus pandemic and the OPEC's inability to reach a production quota agreement. We employ the structural VAR model with time-varying coefficients and stochastic volatility (TVPSVAR model) developed by Primiceri (2005) to asses the impact of COVID-19 shocks on the energy futures markets, particularly on crude oil and natural gas S\&P GS Indexes. The findings confirm that energy commodities S\&P GS Indexes respond to COVID-19 shock that varying over time due to fundamentals factors as well as behavioral and psychological factors.

Using a TVP- SVAR with a stochastic volatility model, they investigate the impact of COVID-19 on the commodity futures market. First, we show the importance of investors expectations

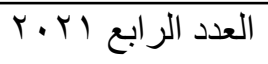

المجلد الثاني عشر 
The Impact of COVID-19 pandemic on the Oil Sector in global economic ...

Dr/ Mona Aboul Atta Halim \& Dr/ Walaa Magdy Rezk

in future commodity price dynamics. Speculators in the futures markets anticipate price movements which caused high stochastic volatility during the period that precedes the huge increase in the number of deaths. Then, we show that commodity responses to COVID-19 shock varied from one period to another. The determinants likely to explain the dynamics of the SP GSCI Crude oil index and SP GSCI natural gas index face the COVID19 include fundamental factors as well as financial factors. In fact, the fall in oil futures prices is partly due to a structural imbalance between supply and demand particularly a strong decreasing of energy demand following the COVID 19 in large emerging countries such as China and an oil shock caused by disagreements between the Organization of the Petroleum Exporting Countries (OPEC) and Russia, triggering the drop in oil spot prices. In addition, the spread of the virus in the USA negatively impacted the commodity futures market. On the other side, based on behavioral finance theorist, the commodity indices fluctuations are linked to the investors' expectations. In fact, during the crisis, speculators operating on a purely financial logic, turned to the commodity markets to increase their returns which lead to a slight increase in commodity futures index during stock market crash. The short-term outlook for the commodity futures market will depend on the efficiency of government policy to contain the COVID-19 outbreak, and to weaken the impact of the global health crisis has on economic activity.

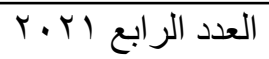$$
\text { المجلد الثاني عشر - - ان }
$$ 
The Impact of COVID-19 pandemic on the Oil Sector in global economic ...

Dr/ Mona Aboul Atta Halim \& Dr/ Walaa Magdy Rezk

Recently many studies investigated COVID-19's impact on global economic activity. Yilmazkuday (2020), by using daily data on the global coronavirus disease 2019 (COVID-19) deaths, shows that the effect of COVID-19 deaths is insignificant, and explained the plunge of oil price on March 2020 by the OPEC disagreement. In the same line of work, Maijama'a et al. (2020) investigates the impact of coronavirus outbreak on the global energy demand by using daily data on china's population, currency Chinese exchange rate and international crude oil prices, from 23rd January to 8th February 2020. The result revealed that the total population has a positive and significant impact on total coronavirus infected cases while the crude oil price is negative and significantly related to the coronavirus infected cases.

\section{3- Oil production (American crude) and OPEC countries and} oil prices in the period 2011-2020:

Oil prices ranged 2012 - 2020 between $\$ 110$ in 2011 and below the dollar per barrel in 2020, decreased in 2015 and ranged to $\$ 80$ and below $\$ 30$ per barrel until 2020. It is worth noting that there are two types of American crude Both are used as a benchmark for setting world oil prices:

- The first type: West Texas Intermediate (WTI) oil. It is extracted from oil fields in the United States, especially from Texas, Louisiana and North Dakota, and then transported via a pipeline to Cushing, Oklahoma, for 
The Impact of COVID-19 pandemic on the Oil Sector in global economic ...

Dr/ Mona Aboul Atta Halim \& Dr/ Walaa Magdy Rezk

delivery. WTI is used as the benchmark for determining the price of oil in North America.

- The second type: Brent Crude, extracted from oil fields in the North Sea, which is a mixture of four crude oils, but collectively referred to as "Brent Crude Oil" (Wingfield, Others, 2020).

Brent crude is the most traded globally and is used as a standard for global pricing and measurement. Brent crude and West Texas are classified as relatively light oils.

Figure No. 1

Oil prices (Brent crude) in the period 2011-2020 (dollars per barrel)

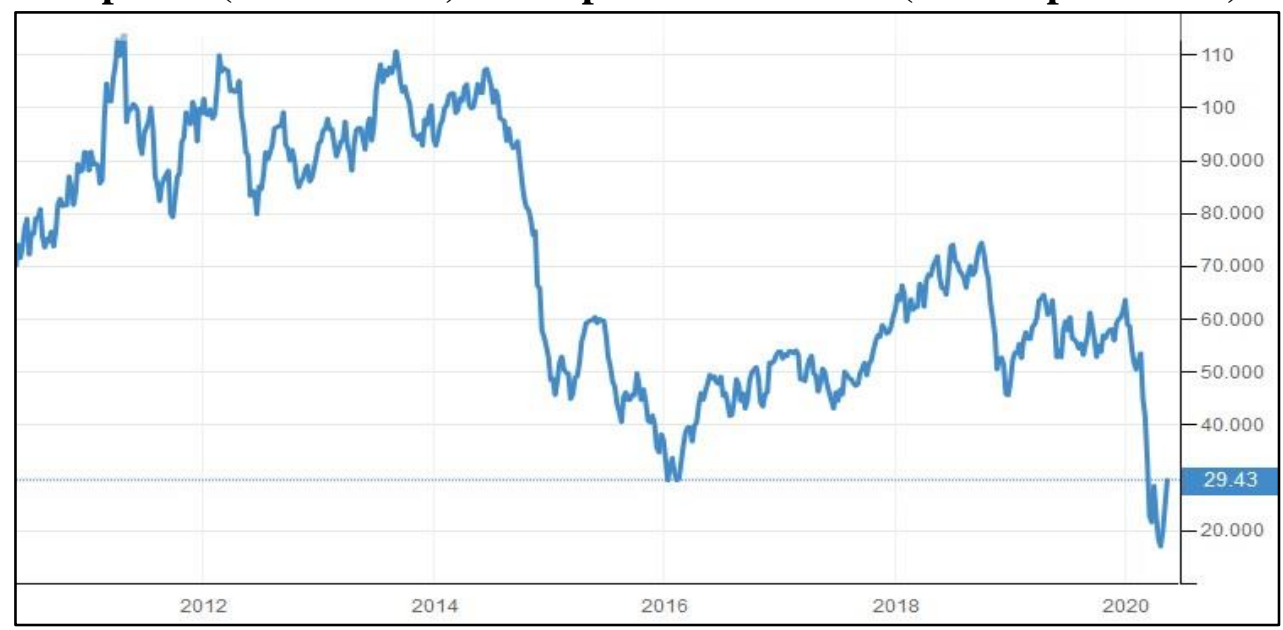

Source: TRADINGECONOMIES.COM (2020).

These prices mentioned in the previous figure refer to the prices of American crude (Brent), as it is considered the main reference for

العدد الر ابع ب.r.r 
The Impact of COVID-19 pandemic on the Oil Sector in global economic ...

Dr/ Mona Aboul Atta Halim \& Dr/ Walaa Magdy Rezk

oil prices and purchases in the world Major Benchmark Price for purchases of oil worldwide. Brent prices have fallen to nearly $\$ 20$, compared to previous years, when they reached the ceiling of $\$ 100$ a barrel. As for the oil whose price has reached below zero (37-), it is WTI, as shown in the following figure (Amadeo, 2020).

\section{Figure No. 2}

US WTI crude price collapse below zero in April 2020

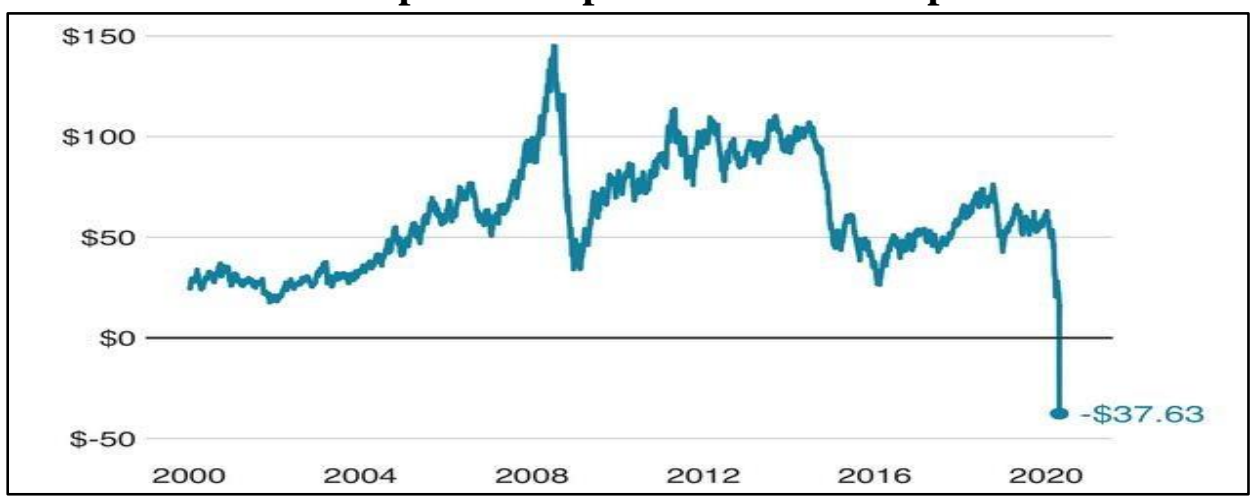

Source: Bloomberg, 27 April 2020.

West Texas Intermediate was trading at a higher price than Brent crude, and due to the revolution in shale oil production in the United States in early 2000, along with more imports to the United States from Canada, the price of WTI decreased, and it is now usually trading at a price Low on Brent. But in general, there are no major differences between the prices of Brent crude and West Texas crude, as shown in the following figure in the last five months. It also indicates the decrease of WTI prices to

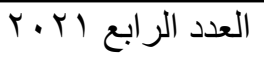

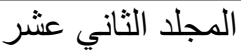


The Impact of COVID-19 pandemic on the Oil Sector in global economic ...

Dr/ Mona Aboul Atta Halim \& Dr/ Walaa Magdy Rezk

below zero last April and then returning to rise again, but below the levels recorded in the months Previous (Sharma, 2020)

Figure No. 3

Oil prices for: Brent, OPEC basket, and WTI from December 2019 to May 2020

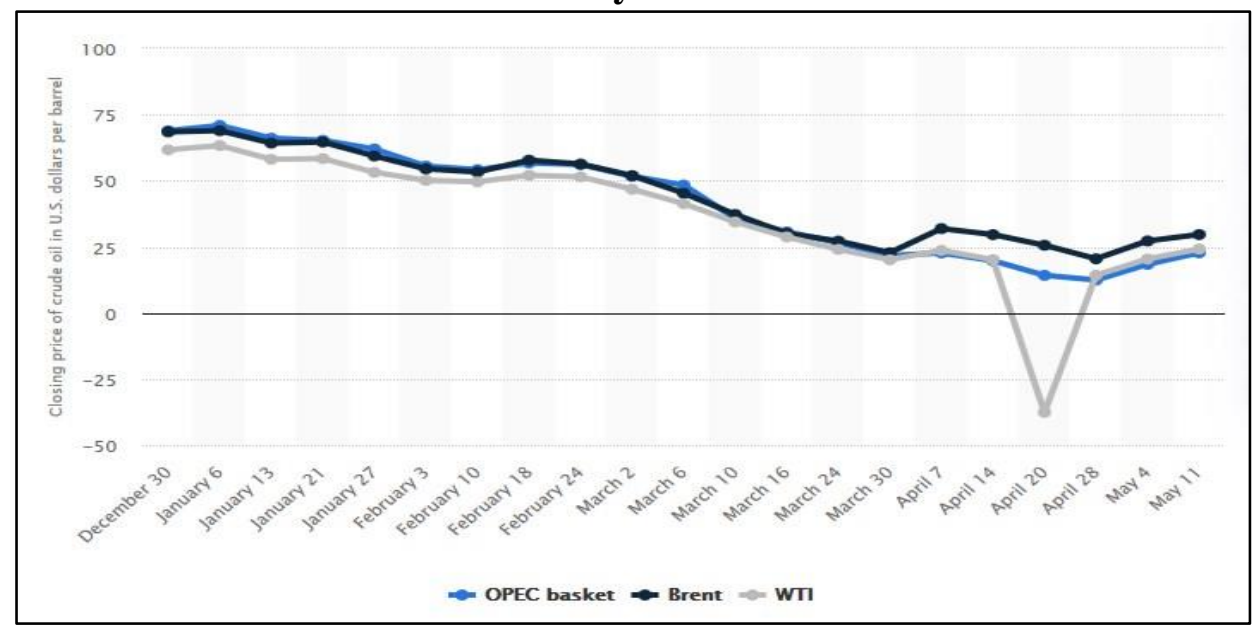

Source: $\underline{w w w . s t a t i s t a . c o m}$

The total oil production in the world is between 100 and 105 million barrels per day, of which 41-43 million barrels are produced by OPEC countries daily. OPEC controls approximately $75 \%$ of the total crude oil reserves in the world and produces $42 \%$ of the total crude oil production in the world. Before the Corona pandemic, the supply of oil was greater than the demand for it (global demand $=90$ million barrels per day), equivalent to 12-15 million barrels per day. Since the United States is the largest producer and consumer, as well as an importer of oil in the world, producing close to 12 million barrels

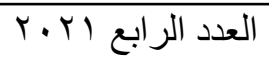$$
\text { المجلد الثاني عشر }
$$ 
The Impact of COVID-19 pandemic on the Oil Sector in global economic ...

Dr/ Mona Aboul Atta Halim \& Dr/ Walaa Magdy Rezk

per day, until 2012, it used to import about 5 million barrels per day from all over the world. but as of that year, the United States began to rely on "shale gas and shale oil", and paid attention to everything related to extractive industry to not fall under the pressure of the oil producing countries. Since that time, American oil production increased to reach 13 million barrels per day in early 2020, after it was only 8 million barrels in 2014, as shown in the following figure.

Figure No. 4

The development of American crude production in the period 20112020 (thousand barrels)

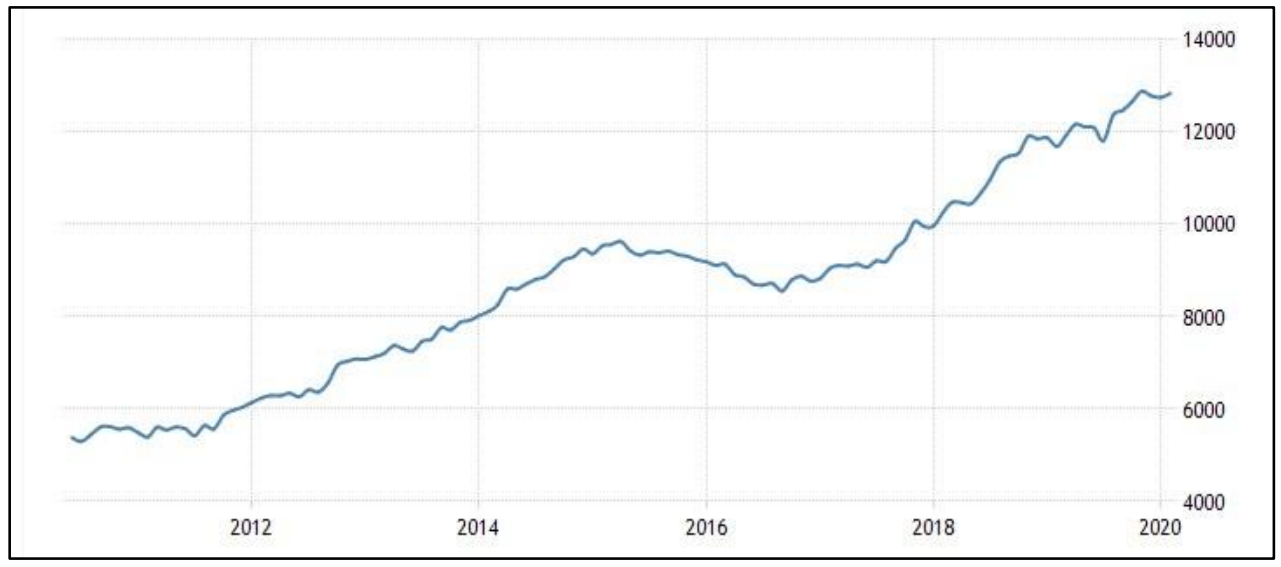

Source: TRADINGECONOMIES.COM 2020, U.S. Energy Information administration.

\section{3- Reasons for the recent sudden collapse of oil prices in late} April 2020?

When the world invaded the newly emerging epidemic of 19COVID, countries did not think that a comprehensive ban would

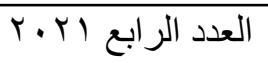$$
\text { المجلد الثاني عشر }
$$ 
The Impact of COVID-19 pandemic on the Oil Sector in global economic ...

Dr/ Mona Aboul Atta Halim \& Dr/ Walaa Magdy Rezk

be imposed in all sectors and at all levels in the manner we are witnessing today, but the United States did not expect the pandemic to extend to it in this way and cause economic life to stop in all Countries of the world, and as a result, the demand for oil decreased significantly.

If we look at Kuwait and the Kingdom of Saudi Arabia as two countries that depend on oil and its exports at $90 \%$ of their national product for each of them, and assuming that Saudi Arabia exports 3 million barrels per day, their value before 2016 was approximately $\$ 400$ million, and today their value is only $\$$ 120 million, meaning that A loss of $\$ 300$ million per day and $\$ 9$ billion per month that would harm the Saudi economy, likewise in Arab economies dependent on oil.

The value of futures contracts for US crude fell unprecedentedly, as the price of a barrel fell to minus $\$ 37$, the lowest level since the beginning of the sale of futures contracts in 1983, which are obligated to sell a specific product at a specific date at specific prices, which has increased the economic pressures that it suffers from during Corona pandemic.

In a deeper view of the American crude market, the buying and selling in the oil market is not done on quantities on time. Rather, there is a circulation of buying and selling contracts between speculators who do not obtain oil in kind, but rather seek to achieve profits only through trading in contracts.

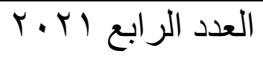

المجلد الثاني عشر 
The Impact of COVID-19 pandemic on the Oil Sector in global economic ...

Dr/ Mona Aboul Atta Halim \& Dr/ Walaa Magdy Rezk

Because of the state of closure and stagnation that prevailed in the world due to the Corona pandemic, a crisis of surplus oil production was generated, while Saudi Arabia and Russia continued to pump large quantities to the market, and with the decrease in demand to stop the movement of air, land and sea navigation, contract holders were no longer able to Sell them, not even able to take the oil drums they had previously bought, because storage places have reached their maximum limits.

Regarding the contracts that are traded on the oil market, there are 3 types of contracts:

- Long-term contracts

- Medium-term contracts

- Spot contracts

The long-term contracts are known to be the least expensive, then medium-term, where prices increase slightly, and the last spot contracts are the most expensive, as they represent the urgent need. Also there are three oil exchanges in the world in which these contracts are traded:

- West Texas Stock Exchange

- Brent Stock Exchange

- Gulf Stock Exchange

In the first type (West Texas) contracts were concluded in May 2020 until 20 April 2020. On the Brent Stock Exchange, June contracts were concluded at $\$ 25$ a barrel, and May contracts closed at $\$ 23$, with an outlook for July of $\$ 30$ a barrel. the Gulf

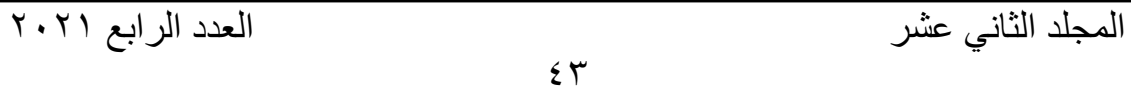


The Impact of COVID-19 pandemic on the Oil Sector in global economic ...

Dr/ Mona Aboul Atta Halim \& Dr/ Walaa Magdy Rezk

Stock Exchange, May, June and July contracts were concluded without any storage problems.

The problem of storage appeared in the United States only, and it became difficult to receive any additional quantities from oil producers, and the cost of storage until June became equivalent to $\$ 40$ a barrel per month, while the cost of producing a barrel is only $\$ 25$, Thus, the cost of storage in two months is $\$ 80$ per barrel.

To get out of this deadlock, which is called the loss-lose situation, which is the worst situation the world has reached, the offer to sell for $\$ 0$ would be better, in order to avoid the cost of storage for two months ( $\$ 80$ per barrel), which happened on Monday, 20 April 2020, but It was required that the sale be negative, meaning that each barrel added 37 dollars, which is better than the product costing 80 dollars storage per barrel / two months. Thus, this solution was to discard WTI stock.

Not all the Brent and Gulf stock exchanges were exposed to this problem, as Gulf oil is directly to the refining markets in India, Korea and Japan, and these markets was far from the oil market turmoil in North America.

Oil prices often change, and prices are affected by a wide range of factors, the most important of which are:

- Increase or decrease in supply by oil producers.

- Increase or decrease in demand by oil users and importers.

- Subsidies to oil companies or other energy companies. 
The Impact of COVID-19 pandemic on the Oil Sector in global economic ...

Dr/ Mona Aboul Atta Halim \& Dr/ Walaa Magdy Rezk

- International policy (agreements concluded between countries).

- The internal policy of oil producers.

- Oil supply worldwide.

- Competition from other energy sources.

- Geopolitical disturbances, pressures, and insecurity (leads to an increase in prices).

the global oil price curve will rise in light of:

- The tendency to reduce production due to lower demand, and hence a decrease in the amount of surplus or stock.

- The return of economic and air to work in most countries of the world, as the weakness of the global economy has an adverse effect that would reduce the demand for oil.

The price of a barrel of oil will rise to $\$ 40-\$ 60$, which is the fair price of oil after adding variable costs to the production cost, which is estimated at $\$ 23$ a barrel, while variable costs range between $\$ 15$ and $\$ 25$ a barrel, and selling at any price below that constitutes Loss of the product. Also, the lower price than the fair price pushes small producers (whose production ranges between 7 and 10 million barrels per day) out of the market (Bloomberg, 2020).

4- The impact of the 19-COVID pandemic on the world's

\section{economies:}

Before examining the economic effects of changes in the oil market and its prices on the global economies and the Saudi

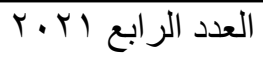

المجلد الثاني عشر 
The Impact of COVID-19 pandemic on the Oil Sector in global economic ...

Dr/ Mona Aboul Atta Halim \& Dr/ Walaa Magdy Rezk

economy in particular, it is necessary to identify the most important effects of the Corona pandemic through exposure to the most important economic indicators summarized in the following table to know the impact of the pandemic on economic performance in those countries (Sönnichsen, 2020).

\section{Table No. 1}

Some economic indicators in some economies in 2018/2019

\begin{tabular}{|c|c|c|c|c|c|c|}
\hline $\begin{array}{c}\text { The indicator } \\
\text { Country }\end{array}$ & $\begin{array}{c}\text { The Growth } \\
\text { Rate } \\
\text { Economic }\end{array}$ & $\begin{array}{c}\text { The interest } \\
\text { rate }\end{array}$ & $\begin{array}{c}\text { The rate of } \\
\text { inflation }\end{array}$ & $\begin{array}{c}\text { The } \\
\text { unemploym } \\
\text { ent rate }\end{array}$ & $\begin{array}{c}\text { Budget } \\
\text { deficit }\end{array}$ & $\begin{array}{c}\text { Public debt / } \\
\text { GDP }\end{array}$ \\
\hline United State & $0.3 \%$ & $0.25 \%$ & $0.3 \%$ & $14.7 \%$ & $-4.60 \%$ & $106.90 \%$ \\
\hline China & $-6.8 \%$ & $3.85 \%$ & $3.3 \%$ & $6 \%$ & $-2.80 \%$ & $50.50 \%$ \\
\hline Euro-zone & $-3.2 \%$ & $0.0 \%$ & $0.3 \%$ & $7.4 \%$ & $-0.60 \%$ & $84.10 \%$ \\
\hline Japan & $-2 \%$ & $-0.10 \%$ & $0.1 \%$ & $2.5 \%$ & $-3.80 \%$ & $238.20 \%$ \\
\hline United Kingdom & $-1.6 \%$ & $0.10 \%$ & $0.8 \%$ & $3.9 \%$ & $-1.80 \%$ & $80.80 \%$ \\
\hline India & $4.7 \%$ & $4 \%$ & $5.84 \%$ & $7.8 \%$ & $-3.34 \%$ & $69.62 \%$ \\
\hline Brazil & $1.7 \%$ & $3 \%$ & $2.4 \%$ & $12.2 \%$ & $-5.90 \%$ & $75.79 \%$ \\
\hline Russia & $1.6 \%$ & $5.5 \%$ & $3.1 \%$ & $4.7 \%$ & $1.80 \%$ & $14.60 \%$ \\
\hline Canada & $1.5 \%$ & $0.25 \%$ & $-0.2 \%$ & $13 \%$ & $-0.70 \%$ & $89.70 \%$ \\
\hline South Korea & $1.3 \%$ & $0.75 \%$ & $0.1 \%$ & $3.8 \%$ & $-1.60 \%$ & $36.60 \%$ \\
\hline Saudi & $\mathbf{- 0 . 3 \%}$ & $\mathbf{1 . 0 \%}$ & $\mathbf{1 . 3 \%}$ & $\mathbf{5 . 7 \%}$ & $\mathbf{- 9 . 2 0 \%}$ & $\mathbf{1 9 . 1 0 \%}$ \\
\hline UAE & $1.6 \%$ & $1.5 \%$ & $-1.9 \%$ & $2.64 \%$ & $-0.80 \%$ & $18.60 \%$ \\
\hline Egypt & $5.6 \%$ & $9.25 \%$ & $5.9 \%$ & $7.7 \%$ & $-8.00 \%$ & $90.00 \%$ \\
\hline Singapore & $-2.2 \%$ & $0.09 \%$ & $0.0 \%$ & $2.4 \%$ & $-0.30 \%$ & $126.30 \%$ \\
\hline Iran & $1.8 \%$ & $18 \%$ & $19.8 \%$ & $10.4 \%$ & $-4.40 \%$ & $44.20 \%$ \\
\hline South Africa & $-0.5 \%$ & $3.75 \%$ & $4.1 \%$ & $29.1 \%$ & $-6.30 \%$ & $62.20 \%$ \\
\hline
\end{tabular}

Source: TRADINGECONOMIES (2020) https://tradingeconomics.com/

When looking at the indicators it is necessary to look at them somewhat conservatively, especially indicators of Saudi, because these indicators were calculated by the end of the fiscal year in June 2019, and not in December 2019 as in other countries. That is, the impact of the COVID -19 pandemic has not yet appeared

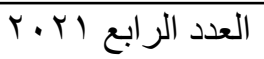

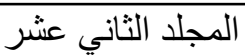


The Impact of COVID-19 pandemic on the Oil Sector in global economic ...

Dr/ Mona Aboul Atta Halim \& Dr/ Walaa Magdy Rezk

in economic indicators, Noting that there is an estimate of some indicators for some countries that were calculated in the first quarter of 2020, which makes them appear somewhat deteriorated, as shown in the unemployment rate in the United States $(14.7 \%)$, the growth rate in China $(-6.8 \%)$, The growth rate in the euro area $(-3.2 \%)$, in addition to the increase in the ratio of public debt to gross domestic product in countries that achieved negative growth at the end of the first quarter of this year (Trading Economies, 2020).

If we look at, for example, the rate of unemployment in Saudi Arabia and its development in the period July 2017 - January 2020, we find that it has made remarkable progress at the last estimate of $5.7 \%$, as shown in the following figure :

Figure No. 5

The unemployment rate in Saudi Arabia (January 2017 - January 2020)

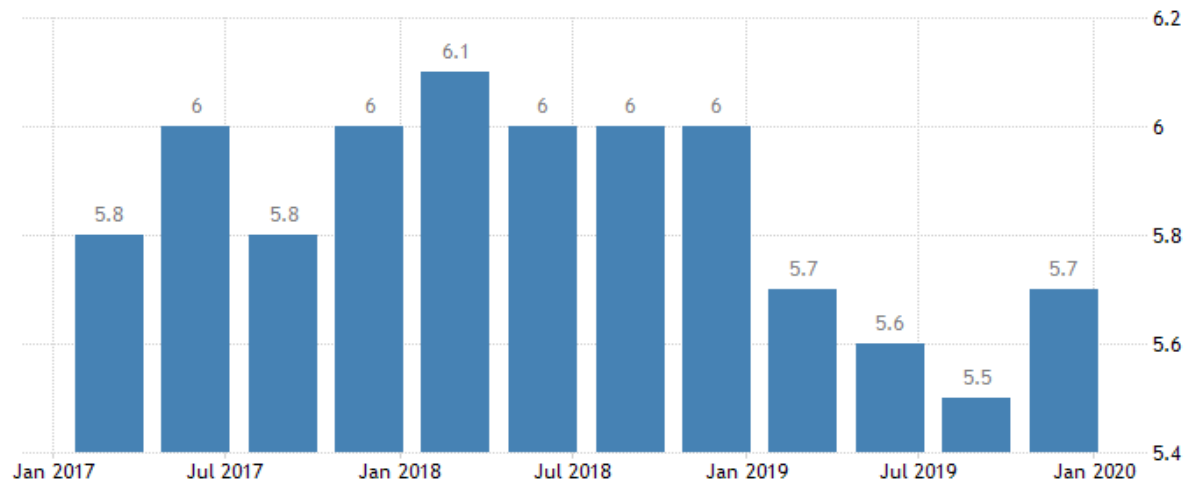

Source: TRADINGECONOMIES.COM 2020, CAPMAS, Saudi Arabia.

العدد الر ابع ب.r.r

المجلد الثاني عشر 
The Impact of COVID-19 pandemic on the Oil Sector in global economic ...

Dr/ Mona Aboul Atta Halim \& Dr/ Walaa Magdy Rezk

\section{The expected effects of changes in the oil market and its prices on Arab and Saudi economies during Corona pandemic:}

It is noted in recent years that the world is on the way to reducing dependence on oil as an energy source, and therefore has a direct negative impact on oil prices. But at the same time, oil remains an irreplaceable source of energy in many areas with other sources of energy. The natural resources that exist in the world, such as minerals, timber, and textiles, will not be enough for the inhabitants of the earth at one time, so the alternative is "the petrochemical industry".

Therefore, we find the policy of Arab countries, including the Gulf states, especially Saudi Arabia, to establish a number of advanced refineries to encourage the manufacturing industry by relying on oil, and then export those products and move as far as possible from the export of oil as crude.

we can say that the Arab common market and the creation of an integrative market among the countries of the region is a real opportunity, and Arab economies should work in this direction, because it will achieve a great added value that is not comparable to that generated from the export of crude oil.

Demand for oil declined due to the emerging Corona Virus "Covid - 19", which pushed the price of oil down, and consequently, the Kingdom's oil revenues decreased to increase the fiscal deficit with it.

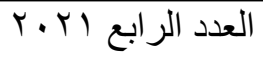

المجلد الثاني عشر 
The Impact of COVID-19 pandemic on the Oil Sector in global economic ...

Dr/ Mona Aboul Atta Halim \& Dr/ Walaa Magdy Rezk

Demand for oil has fallen historically due to the emerging Corona Virus "Covid-19", which caused the oil price crash to an unprecedented degree. Government oil revenues decreased in the first quarter of 2020 by $24.0 \%$ from the same quarter of the previous year, to record 129.0 billion Saudi riyals. This was accompanied by increased expenditures, bringing the budget deficit in the first quarter of 2020 to 34.1 billion Saudi. With the weak expectations of oil demand continuing until the end of 2020, due to the decline in economic activities, high financial spending and decreased financial revenues, we expect the Kingdom to record this year the largest historical deficit in its budget. Early estimates are that the Kingdom's budget deficit will range between 420 and 370 billion Saudi riyals. The longer the epidemic spreads, the greater the impact on the economy.

\section{6-Model and Methodology}

The study try to investigate the short-run and long-run asymmetric effect of oil price changes on the aspects of the government budget in Saudi Arabia. The study use the nonlinear ARDL approach.

The asymmetric integration interrelationship can be written in the following form:

$$
y_{t}=\gamma^{+} z_{t}^{+}+\gamma^{-} z_{t}^{-}+\varepsilon_{t}
$$

Where $y_{t}$ is the dependent series, $z_{t}^{+}$and $z_{t}^{-}$are the partial summation of negative and positive developments in $z_{t}$, and $\varepsilon_{t}$ is the error component. In addition, $\gamma^{+}$and $\gamma^{-}$measure the long

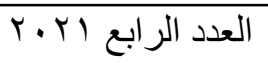$$
\text { المجلد الثاني عشر }
$$ 
The Impact of COVID-19 pandemic on the Oil Sector in global economic ...

Dr/ Mona Aboul Atta Halim \& Dr/ Walaa Magdy Rezk

run asymmetric impact for positive and negative changes respectively.

$$
\begin{aligned}
& z_{t}^{-}=\sum_{i=1}^{t} \Delta z_{i}^{-}=\sum_{i=1}^{t} \max \left(\Delta z_{i}, 0\right) \\
& z_{t}^{+}=\sum_{i=1}^{t} \Delta z_{i}^{+}=\sum_{i=1}^{t} \max \left(\Delta z_{i}, 0\right)
\end{aligned}
$$

Therefore, The asymmetric effect of oil price changes on the different aspects of government budget can be expressed as follows:

$$
\begin{aligned}
y_{t}=\rho y_{t-1} & +\sum_{k=0}^{p-1} \vartheta_{k}^{+} O P_{t}^{+}+\sum_{k=0}^{p-1} \vartheta_{k}^{-} O P_{t}^{-}+\sum_{k=1}^{p-1} \varphi_{y k} \Delta y_{t-k} \\
& +\sum_{k=1}^{q} \varphi_{k}^{+} \Delta O P_{t}^{+}+\sum_{k=1}^{q} \varphi_{k}^{-} \Delta O P_{t}^{-}+\varepsilon_{t}
\end{aligned}
$$

Where, ' $y_{t}$ represents the different aspects of public budget, $\varepsilon_{t}$ reflects the error component, $\gamma^{+}=-\vartheta^{+} / \rho$ and $\gamma^{+}=-\vartheta^{+} / \rho$ reflect the asymmetric long run coefficients.

In order to check for the existence of the cointegration relation in (4), we will follow Shin et al. (2014) by utilizing the Pesaran (2001)'s cointegration bound $\left(F_{p s s}\right)$ test. Which depends on $\mathrm{F}$ test. $F_{p s s}$ based on the null hypothesis that there is no cointegration in the underlying relationship; it means the joint summation for the long run coefficients are equal to zero or $\rho=\vartheta^{+}=\vartheta^{-}=0$. Therefore, refusing the null hypothesis

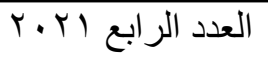$$
\text { المجلد الثاني عشر }
$$ 
The Impact of COVID-19 pandemic on the Oil Sector in global economic ...

Dr/ Mona Aboul Atta Halim \& Dr/ Walaa Magdy Rezk

means that the existence of the long run cointegration in the underlying relationship. Moreover, usual Wald test can by utilized to test for the asymmetry in short and long run relationship.

\section{Data}

The paper explores the hypothesis that changes in the crude oil price would have a considerable impact on government budget; total government expenditure, current government expenditure, capital government expenditure, total government revenue, and the ratio of surplus or deficit to the GDP in Saudi Arabia. The data covers annual data for the years 1990 to 2020 for West Texas Intermediate crude oil price, total government expenditure, current government expenditure, capital government expenditure, total government revenue, and the ratio of surplus or deficit to the GDP. The dataset is captured from IFS and the General Authority for Statistics in Saudi Arabia.

Table (1) shows the descriptive statistics for the raw data of the utilized variables where Table (2) depicts unit root tests for the variables. The ARDL model has one condition is that employed series are integrated of order $\mathrm{I}(0)$ or $\mathrm{I}(1)$ and it is not allowed to be integrated of order I(2). We depend on Augmented Dickey Fuller test to check for the unit root. As it is shown in Table (2), all variables are stationary in the level of the first difference and there is no any series is stationary in the second difference; which means it is appropriate to apply ARDL model.

$$
\text { العدد الرابع ا ب r }
$$$$
\text { المجلد الثاني عشر }
$$ 
The Impact of COVID-19 pandemic on the Oil Sector in global economic ...

Dr/ Mona Aboul Atta Halim \& Dr/ Walaa Magdy Rezk

Table1.Descriptive statistics for variables

\begin{tabular}{|c|c|c|c|c|c|c|}
\hline & OP & TGR & TGX & CGX & CPGX & DCGDP \\
\hline Mean & 33.13043 & 335243.2 & 315143.7 & 227375.8 & 87767.87 & 1.610638 \\
\hline Median & 20.82000 & 205500.0 & 221272.0 & 162350.0 & 54652.00 & -2.600000 \\
\hline Maximum & 110.2200 & 1247398. & 1109903. & 739658.0 & 370245.0 & 43.20000 \\
\hline Minimum & 1.300000 & 7940.000 & 6293.000 & 3989.000 & 2304.000 & -25.30000 \\
\hline Std. Dev. & 29.88969 & 332748.2 & 278764.6 & 196192.7 & 91699.93 & 14.65213 \\
\hline Skewness & 1.410193 & 1.470927 & 1.416078 & 1.217659 & 1.404911 & 0.802962 \\
\hline Kurtosis & 3.904577 & 4.091775 & 4.026157 & 3.551291 & 4.148236 & 3.699688 \\
\hline Jarque-Bera & 17.18013 & 19.28269 & 17.77012 & 12.20960 & 18.04320 & 6.009254 \\
\hline Probability & 0.000186 & 0.000065 & 0.000138 & 0.002232 & 0.000121 & 0.049557 \\
\hline Observations & 47 & 47 & 47 & 47 & 47 & 47 \\
\hline
\end{tabular}

Table2.Unit root results

\begin{tabular}{|c|c|c|c|c|}
\hline & \multicolumn{2}{|c|}{$\mathrm{I}(0)$} & \multicolumn{2}{c|}{$\mathrm{I}(1)$} \\
\hline & $\mathrm{Z}(\mathrm{t})$ & $\mathrm{P}$-value & $\mathrm{Z}(\mathrm{t})$ & $\mathrm{P}$-value \\
\hline OP & -1.566 & 0.4913 & -5.936 & 0.000 \\
\hline TGR & -1.758 & 0.3957 & -7.576 & 0.000 \\
\hline CEXP & -0.431857 & 0.8948 & -8.698 & 0.000 \\
\hline CPEXP & -1.019 & 0.7387 & -5.972 & 0.000 \\
\hline CDGDP & -2.564 & 0.107 & -6.897 & 0.000 \\
\hline
\end{tabular}

Table (3) depicts the results of the linear ARDL for the effect of oil price changes on a public budget. The first and the second column show that over the long run changes in total government revenue is significantly affected by its first lag, the level and the lag of oil price. Over the short run, a change in total government revenue is significantly affected by changes in its lag and changes in the level oil price changes. In addition, the

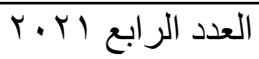$$
\text { المجلد الثاني عشر }
$$ 
The Impact of COVID-19 pandemic on the Oil Sector in global economic ...

Dr/ Mona Aboul Atta Halim \& Dr/ Walaa Magdy Rezk

cointegration term is negative and significant which means the relationship is stable.

Table (3) shows estimates for current government expenditure, capital government expenditure, and total government expenditure. Over the long run, current government expenditure is considerably affected by its lag and the level of oil price where over the long run it is significantly determined by changes in its lag and changes in oil price. Further, table (3) shows that capital government expenditure is significantly affected by its lag and the leg of oil price over the long run. However, over the short run, capital government expenditure is significantly determined by changes in its lag and changes in the level of oil price. Furthermore, table (3) reveals that total government expenditure is significantly affected by its lag, level of oil price and the first lag of oil price. On another hand, over the short run, total government expenditure is significantly affected by changes in its lag and changes in the level of oil price.

Table (3) presents the results for the deficit or the surplus of government budget as a ratio of GDP. It can be observed that over the long run RGDP is significantly determined by its lag, the level of oil price and the lag of oil price. However, over the short run, RGDP is significantly determined by changes in oil price.

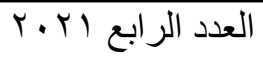

المجلد الثاني عشر 
The Impact of COVID-19 pandemic on the Oil Sector in global economic ...

Dr/ Mona Aboul Atta Halim \& Dr/ Walaa Magdy Rezk

Table (3): Results of the Linear ARDL of Oil Price on the Public

Budget

\begin{tabular}{|c|c|c|c|c|c|c|c|c|c|}
\hline \multicolumn{2}{|c|}{$\begin{array}{l}\text { Total Government } \\
\text { Revenue } \mathrm{D}(T G R)\end{array}$} & \multicolumn{2}{|c|}{$\begin{array}{l}\text { Current Government } \\
\text { Expenditure }\left(C G E_{t}\right)\end{array}$} & \multicolumn{2}{|c|}{$\begin{array}{l}\text { Capital Government } \\
\text { Expenditure }\left(P G E_{t}\right)\end{array}$} & \multicolumn{2}{|c|}{$\begin{array}{l}\text { Total Government } \\
\text { Expenditure } \\
\text { TGE }\end{array}$} & \multicolumn{2}{|c|}{$\begin{array}{l}\text { The ratio of surplus or } \\
\text { deficit to GDP (RGDP) }\end{array}$} \\
\hline $\mathrm{C}$ & $\begin{array}{c}4.521 \\
(0.001)^{* * *}\end{array}$ & $\mathrm{C}$ & $\begin{array}{c}2.658 \\
(0.000)^{* * * *}\end{array}$ & $\mathrm{C}$ & $\begin{array}{c}7.879 \\
(0.000)^{* * * *}\end{array}$ & $\mathrm{C}$ & $\begin{array}{c}4.8718 \\
(0.006)^{* * *}\end{array}$ & $\mathrm{C}$ & $\begin{array}{l}-1.783 \\
(0.717)\end{array}$ \\
\hline$T G R_{t-1}$ & $\begin{array}{c}0.5076 \\
(0.001)^{* * *}\end{array}$ & $C G E_{t-1}$ & \begin{tabular}{|c|}
0.7086 \\
$(0.000) * * *$ \\
\end{tabular} & $P G E_{t-1}$ & $\begin{array}{c}0.489 \\
(0.028)^{* *}\end{array}$ & $T G E_{t-1}$ & $\begin{array}{c}0.525 \\
(0.000)\end{array}$ & $R G D P_{t-1}$ & $\begin{array}{c}0.511 \\
(0.000)^{* * * *}\end{array}$ \\
\hline$O P_{t}$ & $\begin{array}{c}0.995967 \\
(0.000)^{* * *} \\
\end{array}$ & $O P_{t}$ & $\begin{array}{c}0.971 \\
(0.000)^{* * * *}\end{array}$ & $O P_{t}$ & $\begin{array}{c}0.995 \\
(0.013)^{* *} \\
\end{array}$ & $O P_{t}$ & $\begin{array}{c}0.290 \\
(0.0251) \\
\end{array}$ & $O P_{t}$ & $\begin{array}{c}23.14 \\
(0.000)^{* * *} \\
\end{array}$ \\
\hline$O P_{t-1}$ & $\begin{array}{c}0.5059 \\
(0.002) * * *\end{array}$ & $O P_{t-1}$ & $\begin{array}{c}0.104 \\
(0.484)\end{array}$ & $O P_{t-1}$ & $\begin{array}{c}0.09 \\
(0.877)\end{array}$ & $O P_{t-1}$ & $\begin{array}{c}0.316 \\
(0.008) * * *\end{array}$ & $O P_{t-1}$ & $\begin{array}{c}-19.88 \\
(0.000)^{* * *}\end{array}$ \\
\hline $\mathrm{D}\left(T G R_{t-1}\right)$ & $\begin{array}{l}-0.232 \\
(0.2984)\end{array}$ & $\begin{array}{l}\mathrm{D}( \\
\left.C G E_{t-1}\right)\end{array}$ & $\begin{array}{l}-0.1772 \\
(0.541)\end{array}$ & $D\left(P G E_{t-1}\right)$ & $\begin{array}{c}0.0183 \\
(0.034)^{* *}\end{array}$ & $D\left(T G E_{t-1}\right)$ & $\begin{array}{c}0.484 \\
(0.009)\end{array}$ & $D\left(R G D P_{t-1}\right)$ & $\begin{array}{l}-0.0111 \\
(0.9513)\end{array}$ \\
\hline $\mathrm{D}\left(O P_{t}\right)$ & $\begin{array}{c}1.021 \\
(0.000)^{* * * *}\end{array}$ & $\mathrm{D}\left(\begin{array}{l} \\
\left.O P_{t}\right)\end{array}\right.$ & $\begin{array}{c}0.283 \\
(0.000)^{* * *}\end{array}$ & $\begin{array}{c}\mathrm{D}( \\
\left.O P_{t}\right)\end{array}$ & $\begin{array}{c}0.378 \\
(0.07)^{*}\end{array}$ & $\begin{array}{c}\mathrm{D}( \\
\left.O P_{t}\right)\end{array}$ & $\begin{array}{c}0.290 \\
(0.025)^{* *}\end{array}$ & $\begin{array}{c}\mathrm{D}( \\
\left.O P_{t}\right)\end{array}$ & $\begin{array}{c}23.14 \\
(0.000) * * *\end{array}$ \\
\hline $\mathrm{D}\left(O P_{t-1}\right)$ & $\begin{array}{l}0.1692 \\
(0.4662)\end{array}$ & $\mathrm{D}\left(O P_{t-1}\right)$ & $\begin{array}{c}0.181 \\
(0.227)\end{array}$ & $\mathrm{D}\left(O P_{t-1}\right)$ & $\begin{array}{c}0.163 \\
(0.675)\end{array}$ & $\mathrm{D}\left(O P_{t-1}\right)$ & $-0.04(0.81)$ & $\mathrm{D}\left(O P_{t-1}\right)$ & $\begin{array}{l}3.173 \\
(0.55)\end{array}$ \\
\hline$E C T_{t-1}$ & $\begin{array}{l}-0.492 \\
(0.001)\end{array}$ & $E C T_{t-1}$ & \begin{tabular}{c|}
-0.291 \\
$(0.000) * * *$ \\
\end{tabular} & $E C T_{t-1}$ & $\begin{array}{c}-0.38 \\
(0.010)^{* *}\end{array}$ & $E C T_{t-1}$ & $\begin{array}{c}-0.504 \\
(0.000)^{* * *}\end{array}$ & $E C T_{t-1}$ & $\begin{array}{c}-0.488 \\
(0.000) * * *\end{array}$ \\
\hline $\begin{array}{l}\text { Adjusted } \\
R^{2}\end{array}$ & 0.945 & $\begin{array}{l}\text { Adjusted } \\
R^{2}\end{array}$ & 0.954 & $\begin{array}{l}\text { Adjusted } \\
R^{2}\end{array}$ & 0.628 & $\begin{array}{l}\text { Adjusted } \\
R^{2}\end{array}$ & 0.956 & Adjusted $R^{2}$ & 0.709 \\
\hline F-statistic & $\begin{array}{c}260.08 \\
(0.000)^{* * *}\end{array}$ & F-statistic & \begin{tabular}{|c|}
472.25 \\
$(0.000)^{* * * *}$ \\
\end{tabular} & F-statistic & $\begin{array}{c}19.17 \\
(0.000)\end{array}$ & F-statistic & $\begin{array}{l}328.1 \\
(0.00)\end{array}$ & F-statistic & $\begin{array}{c}27.90 \\
(0.000) * * *\end{array}$ \\
\hline D.W & 2.19 & D.W & 2.181 & D.W & 1.855 & D.W & 1.98 & D.W & 2.06 \\
\hline Q-statistic & $\begin{array}{l}0.5750 \\
(0.448)\end{array}$ & Q-statistic & $\begin{array}{l}0.1563 \\
(0.693)\end{array}$ & Q-statistic & $\begin{array}{l}0.0270 \\
(0.987)\end{array}$ & Q-statistic & $\begin{array}{c}0.012 \\
(0.913)\end{array}$ & Q-statistic & $\begin{array}{c}0.057 \\
(0.810)\end{array}$ \\
\hline \begin{tabular}{|l|} 
Heterosced \\
asticity
\end{tabular} & $\begin{array}{l}1.612441 \\
(0.2008) \\
\end{array}$ & $\begin{array}{l}\text { Heterosced } \\
\text { asticity }\end{array}$ & $\begin{array}{c}1.789 \\
(0.150) \\
\end{array}$ & $\begin{array}{l}\text { Heterosceda } \\
\text { sticity }\end{array}$ & $\begin{array}{c}1.143 \\
(0.374) \\
\end{array}$ & $\begin{array}{l}\text { Heterosced } \\
\text { asticity }\end{array}$ & $\begin{array}{c}0.775 \\
(0.514) \\
\end{array}$ & $\begin{array}{l}\text { Heteroscedast } \\
\text { icity }\end{array}$ & $\begin{array}{c}0.775 \\
(0.514) \\
\end{array}$ \\
\hline \begin{tabular}{|l|} 
Serial \\
correlation
\end{tabular} & $\begin{array}{c}0.986 \\
(0.3817) \\
\end{array}$ & $\begin{array}{l}\text { Serial } \\
\text { correlation }\end{array}$ & $\begin{array}{c}1.595 \\
(0.216) \\
\end{array}$ & $\begin{array}{l}\text { Serial } \\
\text { correlation }\end{array}$ & $\begin{array}{l}0.2844 \\
(0.755) \\
\end{array}$ & \begin{tabular}{|l|} 
Serial \\
correlation
\end{tabular} & $\begin{array}{c}0.32 \\
(0.72) \\
\end{array}$ & $\begin{array}{l}\text { Serial } \\
\text { correlation }\end{array}$ & $\begin{array}{l}0.320 \\
(0.72) \\
\end{array}$ \\
\hline $\begin{array}{l}\text { Ramsey } \\
\text { reset }\end{array}$ & $\begin{array}{c}1.309 \\
(0.2591)\end{array}$ & $\begin{array}{l}\text { Ramsey } \\
\text { reset }\end{array}$ & \begin{tabular}{|c|}
2.273 \\
$(0.1398)$
\end{tabular} & $\begin{array}{l}\text { Ramsey } \\
\text { reset }\end{array}$ & $\begin{array}{c}0.397 \\
(0.695)\end{array}$ & $\begin{array}{l}\text { Ramsey } \\
\text { reset }\end{array}$ & $\begin{array}{c}1.15 \\
(0.28)\end{array}$ & Ramsey reset & $\begin{array}{c}1.154 \\
(0.2889)\end{array}$ \\
\hline
\end{tabular}

*** reflects the coefficient is significant with probabilities $1 \%, 5 \%, 10 \%$; ** the coefficient is significant with probabilities $5 \%, 10 \%$; * the coefficient is significant with probability $10 \%$.

Table (4) depicts the estimates for the asymmetric effect of oil price changes on the government budget. The first two columns show factors that effect on total government revenues, we can observe that over the long run total revenues is significantly

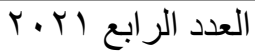


The Impact of COVID-19 pandemic on the Oil Sector in global economic ...

Dr/ Mona Aboul Atta Halim \& Dr/ Walaa Magdy Rezk

affected by its lag, positive and also negative shocks of oil price. However, the effect of positive socks is stronger than negative shocks. Over the short run, the total revenue is considerably only affected by changes in negative oil price shocks. Moreover, the cointegration term is negative and significant which reflects the stability of cointegration relationship.

Table (4) shows the current government expenditure is significantly affected by its lag and the negative oil price shocks. Further, current government expenditure is significantly affected by positive and negative oil price shocks. However, the effect of positive shocks is more obvious than negative shocks. On the other hand, capital government expenditure is significantly affected by its lag and positive oil price shocks over the long run. In addition, capital government expenditure is mainly determined by changes in its lag, changes in the level of positive oil price shocks and the changes in negative oil price shocks. Furthermore, the total government expenditure is mainly determined by its lag, the level of positive oil price shocks and the lag of positive oil price shocks. Contrary, the total government expenditure is significantly affected by changes in its lag, changes in the level and in the lag of positive oil price shocks.

Table (4) presents the results of the asymmetric effect of oil price changes on the ratio of surplus or deficit in the public budget to the GDP. It can be observed that this ratio is considerably affected by its lag, the level of negative and positive shocks of oil

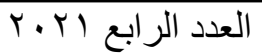$$
\text { المجلد الثاني عشر }
$$ 
The Impact of COVID-19 pandemic on the Oil Sector in global economic ...

Dr/ Mona Aboul Atta Halim \& Dr/ Walaa Magdy Rezk

price and the lag of positive shocks. However, the ratio of the surplus or deficit to GDP is significantly affected by changes in positive shocks and changes in the lag of changes in negative shocks.

In sum, our results support the asymmetric effect of oil price shocks on different aspects of public budget in Saudi Arabia. This is confirmed by the results of Wald test which refer to rejecting the null hypothesis over the short run and long run for the majority of the underlying models.

Table (4): Results of the Non-Linear ARDL of Oil Price on the Public

\section{Budget}

\begin{tabular}{|c|c|c|c|c|c|c|c|c|c|}
\hline \multicolumn{2}{|c|}{$\begin{array}{l}\text { Total Government } \\
\text { Revenue } \mathrm{D}(T G R)\end{array}$} & \multicolumn{2}{|c|}{$\begin{array}{l}\text { Current Government } \\
\text { Expenditure }\left(C G E_{t}\right)\end{array}$} & \multicolumn{2}{|c|}{$\begin{array}{l}\text { Capital Government } \\
\text { Expenditure }\left(P G E_{t}\right)\end{array}$} & \multicolumn{2}{|c|}{$\begin{array}{l}\text { Total Government } \\
\text { Expenditure TGE }\end{array}$} & \multicolumn{2}{|c|}{$\begin{array}{l}\text { The ratio of surplus or } \\
\text { deficit to GDP (RGDP) }\end{array}$} \\
\hline $\mathrm{C}$ & $\begin{array}{l}2.758 \\
(0.25)\end{array}$ & C & $\begin{array}{c}3.805 \\
(0.000) * * *\end{array}$ & $\mathrm{C}$ & $\begin{array}{c}1.27 \\
(0.52)\end{array}$ & C & $\begin{array}{c}6.06 \\
(0.00)^{* * *}\end{array}$ & C & $\begin{array}{c}2.46 \\
(0.58)\end{array}$ \\
\hline$\rho$ & $\begin{array}{c}0.559 \\
(0.00)^{* * * *}\end{array}$ & $\rho$ & $\begin{array}{c}0.597 \\
(0.000) * * *\end{array}$ & $\rho$ & $\begin{array}{c}0.623 \\
(0.000) * * *\end{array}$ & $\rho$ & $\begin{array}{c}0.704 \\
(0.00)^{* * * *}\end{array}$ & $\rho$ & $\begin{array}{c}0.337 \\
(0.016)^{* *}\end{array}$ \\
\hline$\vartheta_{0}^{+}$ & $\begin{array}{c}1.50 \\
(0.00)^{* *}\end{array}$ & $\vartheta^{+}$ & $\begin{array}{l}0.156 \\
(0.39)\end{array}$ & $\vartheta^{+}$ & $\begin{array}{c}1.148 \\
(0.039) * *\end{array}$ & $\vartheta^{+}$ & $\begin{array}{c}0.821 \\
(0.00) * * *\end{array}$ & $\vartheta^{+}$ & $\begin{array}{c}35.82 \\
(0.00)^{* * * *}\end{array}$ \\
\hline$\vartheta_{0}^{-}$ & $\begin{array}{c}0.67 \\
(0.00) * * \\
\end{array}$ & $\vartheta^{-}$ & $\begin{array}{c}0.228 \\
(0.02)^{* *}\end{array}$ & $\vartheta^{-}$ & $\begin{array}{c}0.131 \\
(0.719)\end{array}$ & $\vartheta^{-}$ & $\begin{array}{l}-0.148 \\
(0.484)\end{array}$ & $\vartheta^{-}$ & $\begin{array}{c}19.198 \\
(0.00)^{* * *}\end{array}$ \\
\hline$\vartheta_{1}^{+}$ & $\begin{array}{l}-0.875 \\
(0.11)\end{array}$ & $\vartheta_{1}^{+}$ & $\begin{array}{l}0.171 \\
(0.41)\end{array}$ & $\vartheta_{1}^{+}$ & $\begin{array}{l}0.081 \\
(0.91)\end{array}$ & $\vartheta_{1}^{+}$ & $\begin{array}{c}-0.474 \\
(0.04)^{* *}\end{array}$ & $\vartheta_{1}^{+}$ & $\begin{array}{c}-41.96 \\
(0.00)^{* * *}\end{array}$ \\
\hline$\vartheta_{1}^{-}$ & $\begin{array}{l}-0.262 \\
(0.41)\end{array}$ & $\vartheta_{1}^{-}$ & $\begin{array}{l}-0.004 \\
(0.988)\end{array}$ & $\vartheta_{1}^{-}$ & $\begin{array}{c}0.774 \\
(0.422)\end{array}$ & $\vartheta_{1}^{-}$ & $\begin{array}{l}-0.082 \\
(0.76)\end{array}$ & $\vartheta_{1}^{-}$ & $\begin{array}{c}7.25 \\
(0.34)\end{array}$ \\
\hline$\left.\varphi_{y 1}\right)$ & $\begin{array}{l}-0.206 \\
(0.35)\end{array}$ & $\left.\varphi_{y 1}\right)$ & $\begin{array}{l}-0.092 \\
(0.60)\end{array}$ & $\left.\varphi_{y 1}\right)$ & $\begin{array}{c}-0.298 \\
(0.03) * *\end{array}$ & $\left.\varphi_{y 1}\right)$ & $\begin{array}{c}-0.25 \\
(0.074)^{*}\end{array}$ & $\left.\varphi_{y 1}\right)$ & $\begin{array}{l}-0.08 \\
(0.58)\end{array}$ \\
\hline$\varphi_{0}^{+}$ & $\begin{array}{l}1.503 \\
(0.00) \\
\end{array}$ & $\varphi_{0}^{+}$ & $\begin{array}{c}2.658 \\
(0.000) * * *\end{array}$ & $\varphi_{0}^{+}$ & $\begin{array}{c}1.148 \\
(0.039) * *\end{array}$ & $\varphi_{0}^{+}$ & $\begin{array}{c}0.821 \\
(0.00)^{* * *}\end{array}$ & $\varphi_{0}^{+}$ & $\begin{array}{c}35.8 \\
(0.00)^{* * *}\end{array}$ \\
\hline$\varphi_{0}^{-}$ & $\begin{array}{c}0.673 \\
(0.00)^{* * *}\end{array}$ & $\varphi_{0}^{-}$ & $\begin{array}{c}0.283 \\
(0.00) * * *\end{array}$ & $\varphi_{0}^{-}$ & $\begin{array}{c}0.131 \\
(0.719)\end{array}$ & $\varphi_{0}^{-}$ & $\begin{array}{l}-0.148 \\
(0.48)\end{array}$ & $\varphi_{0}^{-}$ & $\begin{array}{l}-1.78 \\
(0.75)\end{array}$ \\
\hline$\varphi_{1}^{+}$ & $\begin{array}{l}-0.021 \\
(0.95)\end{array}$ & $\varphi_{1}^{+}$ & $\begin{array}{l}-0.065 \\
(0.81)\end{array}$ & $\varphi_{1}^{+}$ & $\begin{array}{c}1.195 \\
(0.024) * *\end{array}$ & $\varphi_{1}^{+}$ & $\begin{array}{c}0.474 \\
(0.0441)^{* *}\end{array}$ & $\varphi_{1}^{+}$ & $\begin{array}{c}-2.2 \\
(0.74)\end{array}$ \\
\hline$\varphi_{1}^{-}$ & $\begin{array}{l}-0.045 \\
(0.89)\end{array}$ & $\varphi_{1}^{-}$ & $\begin{array}{l}0.069 \\
(0.83)\end{array}$ & $\varphi_{1}^{-}$ & $\begin{array}{l}-1.15 \\
(0.29)\end{array}$ & $\varphi_{1}^{-}$ & $\begin{array}{l}-0.482 \\
(0.109)\end{array}$ & $\varphi_{1}^{-}$ & $\begin{array}{c}30.40 \\
(0.00)^{* * *}\end{array}$ \\
\hline$\vartheta_{k}^{+}=\vartheta_{k}^{-}$ & $\begin{array}{c}6.49 \\
(0.015)^{* *}\end{array}$ & $\vartheta_{k}^{+}=\vartheta_{k}^{-}$ & $\begin{array}{c}8.46 \\
(0.006) * * *\end{array}$ & $\vartheta_{k}^{+}=\vartheta_{k}^{-}$ & $\begin{array}{c}4.865 \\
(0.03)^{* *}\end{array}$ & $\vartheta_{k}^{+}=\vartheta_{k}^{-}$ & $\begin{array}{c}4.689 \\
(0.0401)^{* *}\end{array}$ & $\vartheta_{k}^{+}=\vartheta_{k}^{-}$ & $\begin{array}{c}7.90 \\
(0.008)^{* * *}\end{array}$ \\
\hline$\varphi_{k}^{+}=\varphi_{k}^{-}$ & $\begin{array}{c}15.13 \\
(0.00)^{* * * *}\end{array}$ & $\varphi_{k}^{+}=\varphi_{k}^{-}$ & $\begin{array}{c}4.29 \\
(0.045)\end{array}$ & $\varphi_{k}^{+}=\varphi_{k}^{-}$ & $\begin{array}{c}4.97 \\
(0.036) * *\end{array}$ & $\varphi_{k}^{+}=\varphi_{k}^{-}$ & $\begin{array}{c}17.41 \\
(0.00)^{* * * *}\end{array}$ & $\varphi_{k}^{+}=\varphi_{k}^{-}$ & $\begin{array}{c}3.27 \\
(0.051)^{*}\end{array}$ \\
\hline
\end{tabular}

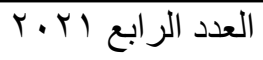

المجلد الثاني عشر 
The Impact of COVID-19 pandemic on the Oil Sector in global economic ...

Dr/ Mona Aboul Atta Halim \& Dr/ Walaa Magdy Rezk

\begin{tabular}{|c|c|c|c|c|c|c|c|c|c|}
\hline \multicolumn{2}{|c|}{$\begin{array}{l}\text { Total Government } \\
\text { Revenue } \mathrm{D}(T G R)\end{array}$} & \multicolumn{2}{|c|}{$\begin{array}{l}\text { Current Government } \\
\text { Expenditure }\left(C G E_{t}\right)\end{array}$} & \multicolumn{2}{|c|}{$\begin{array}{l}\text { Capital Government } \\
\text { Expenditure }\left(P G E_{t}\right)\end{array}$} & \multicolumn{2}{|c|}{$\begin{array}{l}\text { Total Government } \\
\text { Expenditure TGE }\end{array}$} & \multicolumn{2}{|c|}{$\begin{array}{l}\text { The ratio of surplus or } \\
\text { deficit to GDP (RGDP) }\end{array}$} \\
\hline$E C T_{t-1}$ & $\begin{array}{c}-0.306 \\
(0.022)^{* *}\end{array}$ & $E C T_{t-1}$ & $\begin{array}{c}-0.29 \\
(0.002)^{* * *} \\
\end{array}$ & $E C T_{t-1}$ & $\begin{array}{c}-0.078 \\
(0.071)^{*}\end{array}$ & $E C T_{t-1}$ & $\begin{array}{c}-0.043 \\
(0.021)^{* *} \\
\end{array}$ & $E C T_{t-1}$ & $\begin{array}{c}-0.407 \\
(0.00) * * * \\
\end{array}$ \\
\hline \begin{tabular}{|l|} 
Adjusted \\
$R^{2}$ \\
\end{tabular} & 0.945 & $\begin{array}{l}\text { Adjusted } \\
R^{2} \\
\end{array}$ & 0.955 & \begin{tabular}{|l} 
Adjusted \\
$R^{2}$
\end{tabular} & 0.671 & \begin{tabular}{|l|} 
Adjusted \\
$R^{2}$ \\
\end{tabular} & 0.92 & Adjusted $R^{2}$ & 0.84 \\
\hline F-statistic & $\begin{array}{c}41.73 \\
(0.00)^{* * *} \\
\end{array}$ & F-statistic & $\begin{array}{c}241.19 \\
(0.000) * * * \\
\end{array}$ & F-statistic & $\begin{array}{c}6.71 \\
(0.000)^{* * *} \\
\end{array}$ & F-statistic & $\begin{array}{c}31.47 \\
(0.00)^{* * *} \\
\end{array}$ & F-sta & $\begin{array}{c}21.2 \\
(0.00)^{* * * *} \\
\end{array}$ \\
\hline D.W & 2.01 & D.W & 2.02 & D.W & 2.02 & D.W & 1.86 & D.W & 2.1 \\
\hline Q-statistic & $\begin{array}{l}6.471 \\
(0.89) \\
\end{array}$ & Q-statistic & $\begin{array}{r}6.75 \\
(0.87) \\
\end{array}$ & Q-statistic & $\begin{array}{l}10.329 \\
(0.568)\end{array}$ & Q-statistic & $\begin{array}{c}11.14 \\
(0.431)\end{array}$ & Q-statistic & $\begin{array}{l}16.147 \\
(0.185)\end{array}$ \\
\hline $\begin{array}{l}\text { Heterosced } \\
\text { asticity }\end{array}$ & $\begin{array}{c}0.596 \\
(0.856)\end{array}$ & \begin{tabular}{|l|} 
Heterosced \\
asticity
\end{tabular} & $\begin{array}{l}0.525 \\
(0.71)\end{array}$ & $\begin{array}{l}\text { Heterosceda } \\
\text { sticity }\end{array}$ & $\begin{array}{c}1.73 \\
(0.12)\end{array}$ & \begin{tabular}{|l|} 
Heterosced \\
asticity
\end{tabular} & $\begin{array}{c}1.243 \\
(0.305)\end{array}$ & $\begin{array}{l}\text { Heterosceda } \\
\text { sticity }\end{array}$ & $\begin{array}{l}0.505 \\
(0.92)\end{array}$ \\
\hline $\begin{array}{l}\text { Serial } \\
\text { correlation }\end{array}$ & $\begin{array}{c}0.34 \\
(0.715)\end{array}$ & $\begin{array}{l}\text { Serial } \\
\text { correlation }\end{array}$ & $\begin{array}{c}0.51 \\
(0.60)\end{array}$ & $\begin{array}{l}\text { Serial } \\
\text { correlation }\end{array}$ & $\begin{array}{c}1.60 \\
(0.216)\end{array}$ & $\begin{array}{l}\text { Serial } \\
\text { correlation }\end{array}$ & $\begin{array}{c}0.655 \\
(0.528)\end{array}$ & $\begin{array}{l}\text { Serial } \\
\text { correlation }\end{array}$ & $\begin{array}{c}0.622 \\
(0.544)\end{array}$ \\
\hline $\begin{array}{l}\text { Ramsey } \\
\text { reset }\end{array}$ & $\begin{array}{c}0.520 \\
(0.478)\end{array}$ & $\begin{array}{l}\text { Ramsey } \\
\text { reset }\end{array}$ & $\begin{array}{l}0.420 \\
(0.52)\end{array}$ & $\begin{array}{l}\text { Ramsey } \\
\text { reset }\end{array}$ & $\begin{array}{c}0.647 \\
(0.426)\end{array}$ & $\begin{array}{l}\text { Ramsey } \\
\text { reset }\end{array}$ & $\begin{array}{c}2.30 \\
(0.142)\end{array}$ & $\begin{array}{l}\text { Ramsey } \\
\text { reset }\end{array}$ & $\begin{array}{l}2.19 \\
(0.3)\end{array}$ \\
\hline
\end{tabular}

*** reflects the coefficient is significant with probabilities $1 \%, 5 \%, 10 \%$; ** the coefficient is significant with probabilities $5 \%, 10 \%$; * the coefficient is significant with probability $10 \%$.

7- How did Saudi Arabia face this price crisis in the oil market?

The Kingdom and the oil-exporting countries are experiencing many challenges, as restricting oil production and developments on the supply side are other negative effects added to the slowdown in the growth of the global economy, which affects price stability and thus affect the ability of financial planning for countries. Oil markets witnessed great fluctuations during the year 2019 a as Brent crude prices achieved their lowest levels in January at 2.53 dollars a barrel, and its highest levels in April, to reach $\$ 9.74$ a barrel.

The Kingdom, through its oil policy, seeks to stabilize the global market. Crude Oil, which balances the interests of producers and consumers together and provides the right environment for

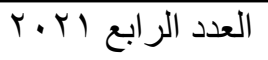$$
\text { المجلد الثاني عشر }
$$ 
The Impact of COVID-19 pandemic on the Oil Sector in global economic ...

Dr/ Mona Aboul Atta Halim \& Dr/ Walaa Magdy Rezk

sustainable growth in the global economy through its active leadership role in commitment in quotas agreed in accordance with the OPEC agreement. Government policies also seek to facing these challenges through diversification of the economic base and developing and diversifying revenues from mon-oil resources to reduce the volatility of financial flows, in addition to strengthening the role of the private sector Emphasis is placed on supporting non-oil GDP growth rates to enhance the economy's resilience. (Ministry of Finince,2020)

\section{The following are important points that can be taken into account when such crises occur and minimize their negative effects on the Saudi market:}

- Encouraging the manufacturing industry and stopping the export of oil or gas in its raw form.

- Relying on alternative sources of electric power generation, which is a global trend sought by different countries of the world, and has many positive consequences and effects, the most important of which is reducing pollution rates. Evidence for this is that the low dependence on petroleum products and the consequent stoppages of flights and land and the stopping of many factories worldwide have had the greatest impact in reducing pollution rates in the world by rates that reached $25 \%$.

- Working to form a fully supply chain in the Arab region, and to use the crude oil produced in one country to produce 
The Impact of COVID-19 pandemic on the Oil Sector in global economic ...

Dr/ Mona Aboul Atta Halim \& Dr/ Walaa Magdy Rezk

finished goods in another country and then export them abroad. (Filipe Barbosa,2020)

- Forming a moderate axis by the oil-producing Arab countries, and not aligned with the Chinese or American poles, considering the global power imbalance. Power is not only a military force, but there is an economic force that will not be achieved in the Arab region except by integration between the countries of the region to form one economic force that produces what is needed and exports what others need.

Saudi Arabia Gasoline Prices

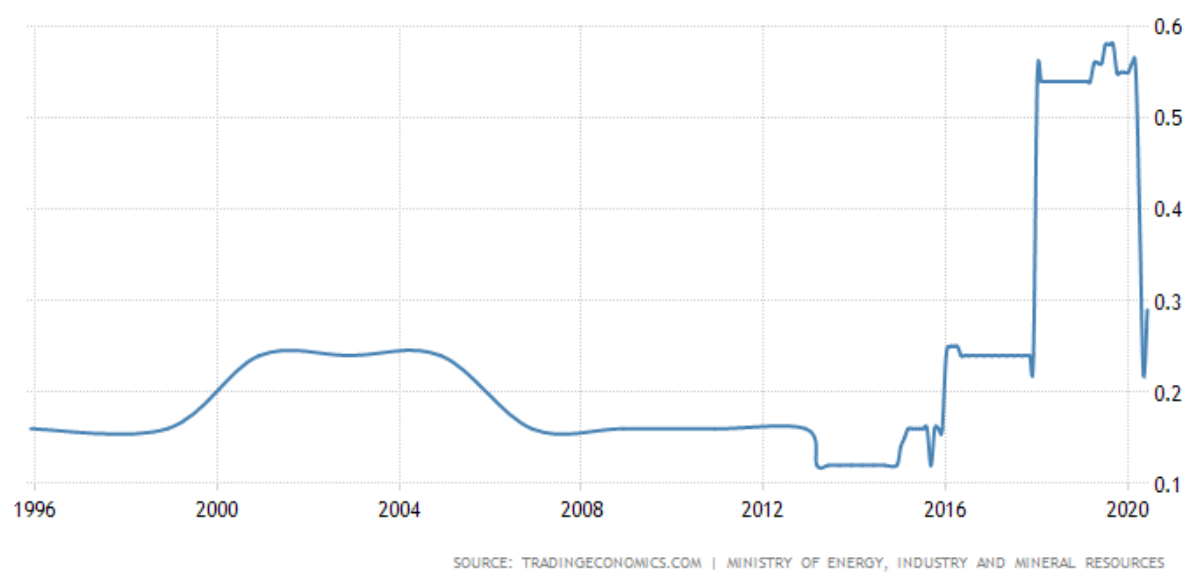

Source: https://tradingeconomics.com/Saudi Arabia/gasoline-

prices

8. Saudi Arabia reforms of energy products prices (Increasing the efficiency of government support):

- The Kingdom has been providing energy products to local consumers at a subsidized price and much less. Of their prices

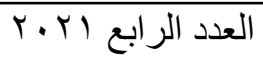

المجلد الثاني عشر 
The Impact of COVID-19 pandemic on the Oil Sector in global economic ...

Dr/ Mona Aboul Atta Halim \& Dr/ Walaa Magdy Rezk

when exporting. The difference between the price of a product domestically and its price when exporting represents the cost of an alternative opportunity per barrel of oil or the benefits that the domestic consumer acquires from the subsidized price.

- The value of government support for energy and water products in 2015 was approximately (300) billion Saudi riyals, based on the export price of energy products at that time. The value of subsidies can increase significantly over time due to the rapid growth of domestic consumption of energy and water products and changes in the export prices of energy products. Subsidized prices also contribute to stimulating rapid growth in the consumption of state resources.

- The Kingdom relies on oil and non-renewable natural resources as a main source of income, and therefore it is not possible in the long run to continue consuming these resources locally in this unfair form and at subsidized prices.

The Kingdom aims to adjust the prices of energy products as the cost of the alternative opportunity wastes on the Kingdom the opportunity to collect the optimum price for its natural resources, and therefore to use those lost revenue in investment in other sectors to achieve economic diversification and provide various benefits for the residential and non-residential sectors.

\section{9-Conclusion}

In this study we presented and shed light on unprecedented crisis for the oil industry which generated from the COVID-19

العدد الر ابع ب.r.r
المجلد الثاني عشر 
The Impact of COVID-19 pandemic on the Oil Sector in global economic ...

Dr/ Mona Aboul Atta Halim \& Dr/ Walaa Magdy Rezk

pandemic demand disruption, and a supply surplus. The oil sector is witnessed its third price collapse in 12 years. After the first two shocks, but this time is different. This one combines a supply shock with an unprecedented demand drop and a global humanitarian crisis. the depth and duration of this crisis are uncertain, this crisis will have a deep impact on the industry, both short and long term. we think, it will be difficult to return to the attractive industry performance without fundamental change.

In the Short-term scenarios for supply, demand, and prices we expected oil prices could recover in 2021 or 2022 to pre - crisis levels of $\$ 50 / \mathrm{bbl}$ to $\$ 60 / \mathrm{bbl}$. We think it will be two years before demand recovers, with the outlook for jet fuel particularly bleak. The immediate effects are already staggering: companies must figure out how to deal with full storage, prices falling below cash costs for some operators.

We think in the long run the macro-environment will become more challenging and we predict growth in demand for oil, to peak in the 2030s, and then begin a slow decline.

The challenge of the energy transition will continue. Saudi Arabia must begin a new age and change in its strategy, where the industry will be entering an era defined by intense competition, technologyled rapid supply response, flat to declining demand.

the unprecedented crisis will be a catalytic moment and accelerate permanent shifts in the industry's ecosystem, with new future opportunities.

$$
\text { العدد الرابع (Yr r }
$$$$
\text { المجلد الثاني عشر }
$$ 
The Impact of COVID-19 pandemic on the Oil Sector in global economic ...

Dr/ Mona Aboul Atta Halim \& Dr/ Walaa Magdy Rezk

\section{References:}

1. ALOUI, Donia (2020), COVID 19'S IMPACT ON CRUDE OIL AND NATURAL GAS S\&P GS Indexes.

https://www.researchgate.net/publication/341029631_COVID_19's_impac t_on_crude_oil_and_natural_gas_SP_GS_Indexes

2. Brian Wingfield, Samuel Dodge, Demetrios Pogkas and Cedric Sam (2020) New Decade, New OPEC Oil Curbs. Same Mixed Results, https://www.bloomberg.com/graphics/opec-production-targets/

3. Filipe Barbosa, Giorgio Bresciani,(2020) Oil and gas after COVID-19: The day of reckoning or a new age of opportunity? McKinsey \& Company PP1-11.

4. Kimberly Amadeo (2020) Oil Price Forecast 2020-2050: How Much Will Oil Prices Drop in 2020 and 2021?, https://www.thebalance.com/oil-priceforecast-3306219

5. Rakesh Sharma (2020) OPEC vs. the US: Who Controls Oil Prices?, https://www.investopedia.com/articles/investing/081315/opec-vs-us-whocontrolsoil-prices.asp

6. Mckinsey \& Company (2020), Oil and gas after COVID-19: The day of reckoning or a new age of opportunity?.

https://www.mckinsey.com/industries/oil-and-gas/our-insights/oil-andgas-after-covid-19-the-day-of-reckoning-or-a-new-age-of-opportunity

7. Ministry of Finance, State general budget statement, Saudi Arabia,2020.

8. Ministry of Finance, the program of achieving the Saudi financial balance, 2020 .

9. N. Sönnichsen (2020) Weekly crude oil prices for Brent, OPEC basket, and WTI 2019-2020, https://www.statista.com/statistics/326017/weeklycrude-oil-prices/

10. Bloomberg (2020) 27 April.

العدد الرابع ابr ·

المجلد الثاني عشر 
The Impact of COVID-19 pandemic on the Oil Sector in global economic ...

Dr/ Mona Aboul Atta Halim \& Dr/ Walaa Magdy Rezk

11. Trading Economies (2020) https://tradingeconomics.com/unitedstates/crude-oilproduction

12. Trading Economies (2020) https://tradingeconomics.com/egypt/gdpgrowth-annual.

13. Yilmazkuday, H. (2020). Coronavirus disease 2019 and the global economy.

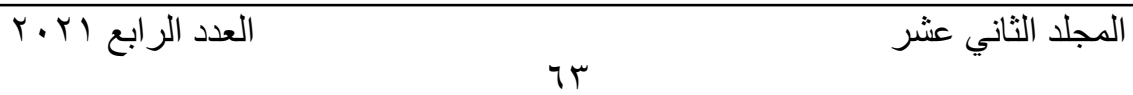


The Impact of COVID-19 pandemic on the Oil Sector in global economic ...

Dr/ Mona Aboul Atta Halim \& Dr/ Walaa Magdy Rezk

\title{
The Impact of COVID-19 pandemic on the Oil Sector in global economic and Saudi Economy
}

\author{
نبذة عن المؤلف \\ د. منى أبو العطا حليم

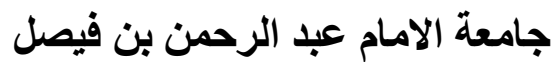 \\ المملكة العربية السعودية الائ \\ mahalim@iau.edu.sa \\ ORCID-ID: 0000-0001-9075-2801 \\ أستاذ مساعد ورئيس قسم العلوم المالية، جامعة الامام عبد الرحمن بن فيصل، قامت بالتدريس في

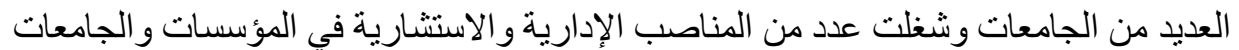

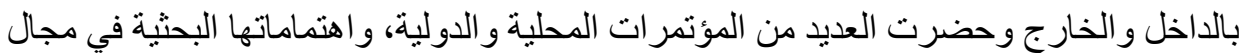

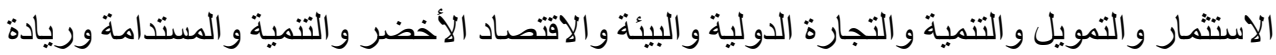

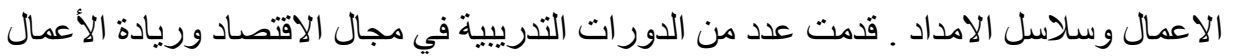

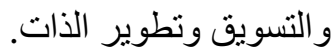

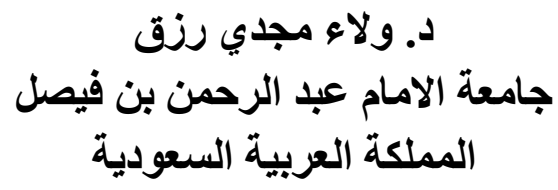 \\ +966501954408 wmrezk@iau.edu.sa \\ ORCID-ID: 0000-0002-6968-977X \\ أستاذ مساعد ورئيس لجنة الاختبار ات، جامعة الإمام عبد الرحمن بن فيصل، قامت التبات بالتدريس في

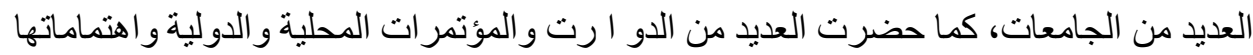

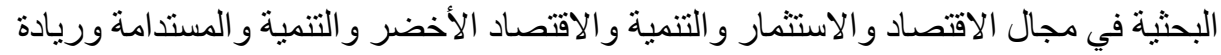

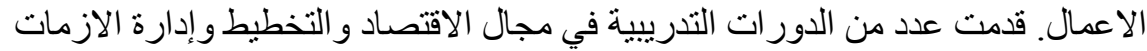 \\ و المهار ات الثخصية وريادة الأعمال
}

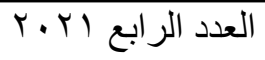

المجلد الثاني عشر 